\title{
EXPERIMENTAL STUDY OF MECHANICAL BEHAVIOUR OF ANGLES IN TRANSMISSION TOWERS UNDER FREEZING TEMPERATURE
}

\author{
L.Q. An ${ }^{1}$, W.Q. Jiang ${ }^{1}$, Y.P. Liu ${ }^{2, *}$, Q. Shi ${ }^{3}$, Y.D. Wang ${ }^{1}$ and S.X. Liu ${ }^{1}$ \\ ${ }^{1}$ Department of Mechanical Engineering, North China Electric Power University, Baoding, \\ Hebei, China \\ ${ }^{2}$ Department of Civil and Environmental Engineering, The Hong Kong Polytechnic University, \\ Hong Kong, China \\ ${ }^{3}$ Electric Power Economic Research Institute of Eastern Inner Mongolia electric power Co., Ltd., \\ Hohhot, China \\ *(Corresponding author: E-mail: ceypliu@polyu.edu.hk)
}

Received: 12 May 2017; Revised: 4 August 2017; Accepted: 25 November 2017

\begin{abstract}
Compared with the lower-grade steel members, the application of steel angles made of Q420 greatly reduces the self-weight of lattice transmission tower and further leads to the saving of foundation cost. However, unlike the conventional transmission towers, the strength and brittleness of the towers using higher-grade steel are more sensitive to freezing temperature, especially in cold regions. It is noted that the studies on transmission line tower at cold region are limited in literature. In this paper, a series of tests such as Charpy impact test, uniaxial tensile test and tensile notch test were carried out at low temperatures to investigate the mechanical properties and toughness of steel angles made of Q235B, Q345B and Q420C as well as welded joints using Q420C. The results show that the toughness of steel angles decreases with the lowing temperature while the strength increases with the decreasing temperature. The heat affected zone in welded joints is more susceptible to fracture than the parent material. A strength reduction method is proposed for the design of transmission tower in cold regions with rich experimental data provided. The influence of stress concentration at low temperatures was also investigated for fracture resistant design.
\end{abstract}

Keywords: Steel angle, low temperature, transmission tower, toughness, notch sensitivity

DOI: $10.18057 /$ IJASC.2018.14.3.9

\section{INTRODUCTION}

Steel materials of strength above $400 \mathrm{MPa}$ become widely used in transmission line engineering due to its light weight and high loading capacity. More importantly, the high strength steel can avoid the largely use of compound sections in the design of transmission towers subjected to heavy loads, which not only brings a more reliable load transfer mechanism but also simplifies the fabrication work. Also, structural engineers may face problems when using the direct analysis to design transmission tower as the initial member imperfection of compound sections has not been given in the design codes such as AISC-LRFD [1] and EC3 [2]. The direct analysis method is a powerful and reliable tool which can well predict the structural behavior of transmission tower considering joint performance [3-4]. Generally speaking, the application of high strength steel can improve the safety and structural performance of transmission engineering with a reduction in fabrication and construction cost.

It should be pointed out that the mechanical properties and toughness of the high-strength steel may be quite different from that of normal steel, due to the different rolling process, crystal phases and chemical components. It is reported that the elongation decreases commonly with the increasing of steel strength, which indicates the lower plastic deformation capacity and ultimate-to-yield strength ratio for higher grade steel as the temperature decreases [5-8]. Obviously, the transmission tower 
made of higher grade steel has higher load-carrying capacity than that made of normal steel. According to the theory of fracture mechanics, the higher strength steel is more sensitive to defect and therefore increases the risk of brittle fracture at low temperature [9-12]. This concern leads to the limited use of higher strength steels such as Q420 and Q460 in transmission towers especially in the low temperature area.

In the past decades, considerable number of steel structures collapsed in cold regions due to brittle fracture. It is reported that the number of tower collapsed at low temperature environment in China has increased several dozen times from 1988 to 2013. It seems that the use of higher strength steel causes severe brittle problems in cold regions of China. For all steel grades, the Chinese structural steel is classified into A, B, C and D. There is no requirement of Charpy impact test for Class A while the temperature of Charpy impact test is $20^{\circ} \mathrm{C}, 0^{\circ} \mathrm{C}$ and $-20^{\circ} \mathrm{C}$ for Class $\mathrm{B}, \mathrm{C}$ and $\mathrm{D}$ respectively. In Chinese market, the steel angles for transmission towers are generally made of Class B and C. Thus, there is an urgent need to verify the performance of steel angles at temperatures lower than $-20^{\circ} \mathrm{C}$ for routine design or evaluation of existing tower in cold regions.

For UHV (Ultra High Voltage) and EHV (Extra High Voltage) transmission towers, their main legs usually consist of multiple angles which are connected by bolts for easy fabrication and transportation. In the process of drilling bolt hole, the commonly used method is punching process, which easily causes microcrack and crack source around the wall of hole. The microcrack will be quickly expanded when the temperature of steel angle is below the ductile-brittle transition temperature. This leads to the failure of bolted joints and further the collapse of the transmission tower.

A typical transmission tower contains four main legs which are the key members to transfer the external loads to the foundation. The brittle failure of main angles at low temperature will lead to the collapse of the tower and further endanger the safe and stable operation of the whole power system. Thus, there is an urgent need of experimental study of the mechanical properties, fracture toughness and notch sensitivity of steel angles used in transmission tower at low temperature. It is of great importance to the design and construction of UHV (Ultra High Voltage) and EHV (Extra High Voltage) transmission lines in cold regions. In this paper, a series of tests such as Charpy impact test, uniaxial tensile test and tensile notch test were carried out at low temperatures to investigate the mechanical properties and toughness of steel angles made of Q235B, Q345B and Q420C as well as welded joints using Q420C. From this study, the strength reduction method and some recommendations is proposed for the design of transmission tower in cold regions.

\section{SETUP OF EXPERIMENTAL TESTS}

In this paper, totally 31 transmission lines (500 kV and above) which are in operation or under construction at the regions of China with annual average temperature below $0^{\circ} \mathrm{C}$ are investigated. Among them, there are 24, 1 and 6 towers for $500 \mathrm{kV}, 660 \mathrm{kV}$ and $750 \mathrm{kV}$ lines respectively. For the minimum temperature in the design stage, there are 9,17 and 5 towers designed for $-40^{\circ} \mathrm{C},-35^{\circ} \mathrm{C}$ and $-30^{\circ} \mathrm{C}$ respectively. These transmission lines are mainly made of steel angles except one named Qingyun-Jixi $500 \mathrm{kV}$ double circuit which used Q345B steel tubes. Six line towers (two $500 \mathrm{kV}$ lines, one $660 \mathrm{kV}$ line and three $750 \mathrm{kV}$ lines) are used Q420B and Q420C steel angles while the other towers are made of Q235B and Q345B steel angles.

Experimental study is the effective approach to investigate the mechanical behaviour of engineering structures [13-15]. To evaluate the actual performance of the towers mentioned above, a series of tests such as Charpy impact test, uniaxial tensile test and uniaxial tensile test with notch were carried out at low temperatures to investigate the mechanical properties and toughness of steel angles made 
of Q235B, Q345B and Q420C. The welded joints using Q420C steel plate were also studied with consideration of different thicknesses to minimize the influence of these parameters due to randomness.

\subsection{Low Temperature Impact Toughness Test}

Various factors such as material processing, accuracy of testing machine, swing and frame fit, test temperature control and location of sample may lead to large discrepancy of the impact test results. Therefore, the number of test samples is generally not less than three.

The Q235B and Q345B steel materials are commonly used in transmission lines. In this paper, four groups of Charpy impact tests in terms of steel grade and member/joint were performed at specified temperature from $100^{\circ} \mathrm{C}$ to $-60^{\circ} \mathrm{C}$ according to the standard $\mathrm{GB} / \mathrm{T} 229-2007$ [16]. The interval is $10^{\circ} \mathrm{C}$ for temperature from $0^{\circ} \mathrm{C}$ to $100^{\circ} \mathrm{C}$ while $5^{\circ} \mathrm{C}$ is used from $-60^{\circ} \mathrm{C}$ to $-5^{\circ} \mathrm{C}$.

The locations and dimensions of the specimens (as seen in Figure 1a) of Q235B and Q345B steel angles for Charpy impact test are determined in accordance with the standard GB/T 229-2007 [16]. The specimens were sampled from the steel angle named L140 $\times 12$ with the location shown in Figure $1 b$.

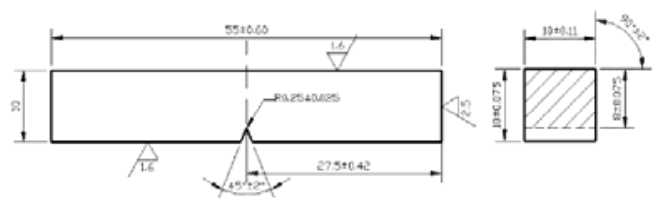

(a) Geometry of Impact Test Specimen

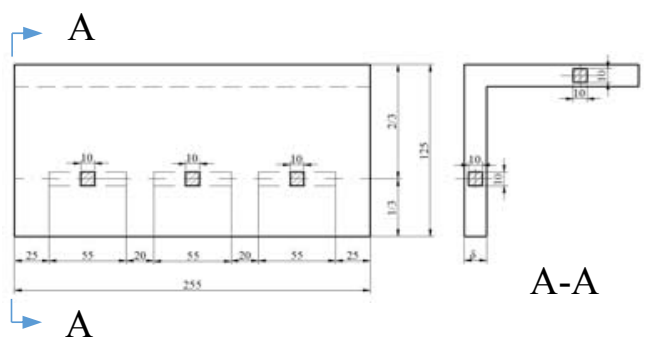

(b) Sampling of Steel Angle

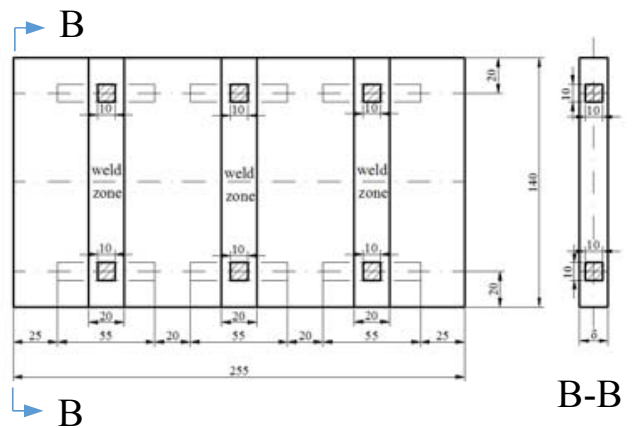

(c) Sampling of Welded Joints

Figure 1. Sampling and Geometry of Impact Test Specimens 
Similarly, the preparation of test specimens of Q420C for Charpy impact test is shown in Figure 1 in accordance with the standard GB/T 229-2007 [16]. The test specimens of Q420C were sampled from

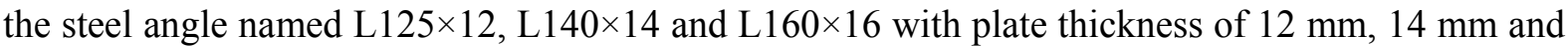
$16 \mathrm{~mm}$ respectively. The Q420C welded joints were sampled from welding plates considering thickness of $12 \mathrm{~mm}, 14 \mathrm{~mm}$ and $16 \mathrm{~mm}$. Three identical samples were made for each specified model and thickness and therefore, there are nine impact test specimens accounting for three different plate thicknesses. The tests were performed at each specified temperature points (i.e. $20,-20,-45,-60^{\circ} \mathrm{C}$ ) according to the standard GB/T 229-2007 [16].

The impact tests are shown and listed in Table 1. In summary, the samples for Charpy impact test have accounted for the influence of steel grade, member/weld joint, plate thickness and temperature change.

Table 1. Impact Test List

\begin{tabular}{ccccc}
\hline Steel grade & Type & $\begin{array}{c}\text { Temperature } \\
\text { range } T /{ }^{\circ} \mathrm{C}\end{array}$ & $\begin{array}{c}\text { Temperature } \\
\text { points } n_{T}\end{array}$ & $\begin{array}{c}\text { Number of } \\
\text { samples } n_{S}\end{array}$ \\
\hline \multirow{2}{*}{ Q235B } & Steel angle & $100 \sim 0$ & 10 & $10 \times 4$ \\
& & $-5 \sim-60$ & 12 & $12 \times 4$ \\
Q345B & Steel angle & $100 \sim 0$ & 10 & $10 \times 4$ \\
& & $-5 \sim-60$ & 12 & $12 \times 4$ \\
Q420C & Steel angle & $20,-20,-45,-60$ & 4 & $4 \times 3 \times 3$ \\
Q420C & Welded joint & $20,-20,-45,-60$ & 4 & $4 \times 3 \times 3$ \\
\hline
\end{tabular}

\subsection{Low Temperature Tensile Tests}

The locations and dimensions of the specimens (as seen in Figure 2a) of Q235B and Q345B steel angles for low temperature tensile test are determined in accordance with the standard GB/T 132392006 [17]. The specimens were sampled from the steel angle named L $140 \times 12$ with the location shown in Figure $2 b$.

Five tensile test specimens were performed at each specified temperature from $20^{\circ} \mathrm{C}$ to $-50^{\circ} \mathrm{C}$ (i.e. 20 , $0,-10,-20,-30,-40,-50^{\circ} \mathrm{C}$ ) according to the standard GB/T 13239-2006 [17].

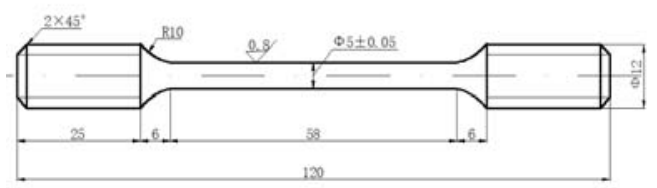

(a) Specimen for Low Temperature Tensile Test

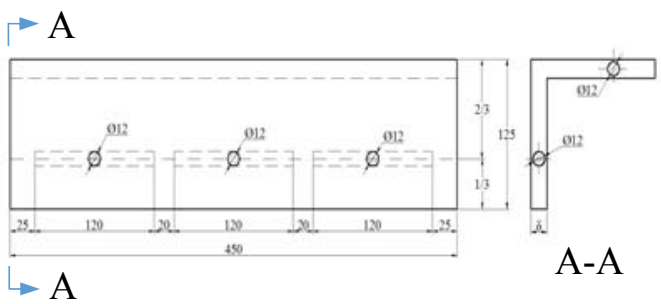

(b) Sampling of Steel Angle 


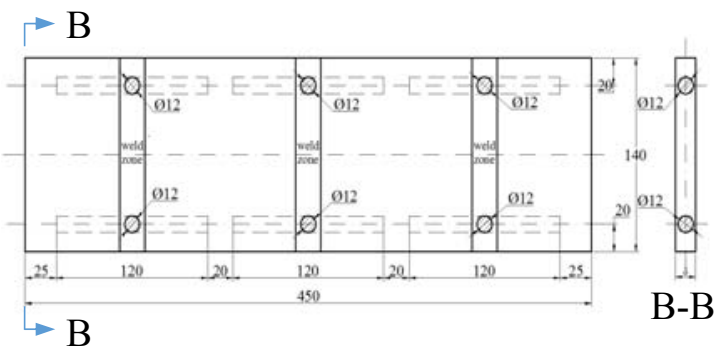

(c) Sampling of Welded Joints

Figure 2. Sampling and Geometry of Tensile Test Specimens

Additionally, mechanical properties of Q420C high-strength steel and its welded joint were determined by smooth tensile test specimens as shown in Figure 2c, which were machined in accordance with the standard GB/T 13239-2006 [17]. Respectively, smooth tensile test specimens of Q420C high-strength steel were sampled from the steel angle named L125 $\times 12$, L140 $\times 14$ and L160×16 (marked as $12 \mathrm{~mm}, 14 \mathrm{~mm}$ and $16 \mathrm{~mm}$ ), and its welded joints were sampled from welding plates with thickness of $12 \mathrm{~mm}, 14 \mathrm{~mm}$ and $16 \mathrm{~mm}$ respectively. Make three identical samples from each specified model and thickness. Then nine replicated tensile test specimens were performed at each specified temperature points (i.e. $20,-10,-20,-45^{\circ} \mathrm{C}$ ) according to the standard GB/T 132392006 [17]. The smooth tensile test list is shown in Table 2.

Table 2. Smooth Tensile Test List

\begin{tabular}{cccc}
\hline Steel grade & Type & $\begin{array}{c}\text { Temperature points } \\
T /{ }^{\circ} \mathrm{C}\end{array}$ & $\begin{array}{c}\text { Number of samples } \\
\left(n_{T} \times n_{S}\right)\end{array}$ \\
\hline Q235B & Steel angle & $20 \sim-50$ & $7 \times 5$ \\
Q345B & Steel angle & $20 \sim-50$ & $7 \times 5$ \\
Q420C & Steel angle & $20,-10,-20,-45$ & $4 \times 9$ \\
Q420C & Welded joint & $20,-10,-20,-45$ & $4 \times 9$ \\
\hline
\end{tabular}

\section{$2.2 \quad$ Notch Sensitivity Tests}

The specimens of Q235B and Q345B for notch sensitivity tensile test were sampled from the steel angle named L140×12. The geometry of the test specimens made of Q235B and Q345B steel angles for notch tensile test is shown in Figure 3. They were prepared in accordance with the standard HB 5214-1996 [18]. The locations and dimensions of the specimens of Q235B and Q345B steel angles for notch tensile test can be seen in Figure $2 b$.

There were five tensile test specimens performed at each specified temperature from $20^{\circ} \mathrm{C}$ to $-50^{\circ} \mathrm{C}$ (i.e. $20,0,-10,-20,-30,-40,-50^{\circ} \mathrm{C}$ ) according to the standard HB 5214-1996 [18]. The notch tensile tests are listed in Table 3.

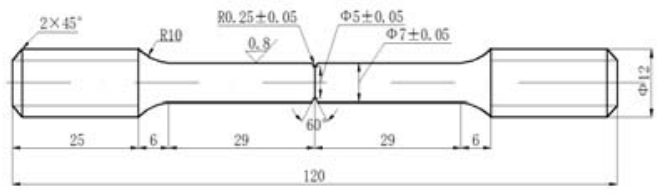

Figure 3. Geometry of Notch Tensile Test Specimens 
Table 3. Notch Tensile Test List

\begin{tabular}{ccc}
\hline Steels & $\begin{array}{c}\text { Temperature points } \\
T /{ }^{\circ} \mathrm{C}\end{array}$ & $\begin{array}{c}\text { Number of samples } \\
\left(n_{T} \times n_{S}\right)\end{array}$ \\
\hline Q235B & $20 \sim-50$ & $7 \times 5$ \\
Q345B & $20 \sim-50$ & $7 \times 5$ \\
\hline
\end{tabular}

\subsection{Experimental Equipment}

As shown in Figure 4a, the machine for testing material properties at low temperature is SANS-50KN. The compressor is used for refrigeration and its lowest operating temperature is $-90^{\circ} \mathrm{C}$. The pendulum impact testing machine with maximum impact energy of 300J was adopted in the impact tests, as seen in Figure 5b. The cooling medium is alcohol and its lowest operating temperature is $-60^{\circ} \mathrm{C}$. These machines are suitable for large quantities of low temperature tests because of high speed and high precision of temperature control. Figure 5a shows a part of the specimens after impact test while Figure $5 \mathrm{~b}$ demonstrates several specimens after tensile test.

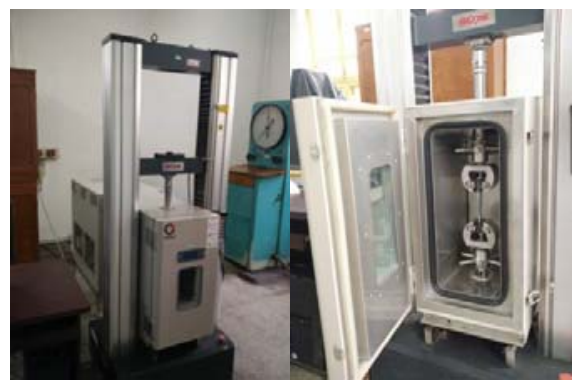

(a) The Tensile Testing Machine

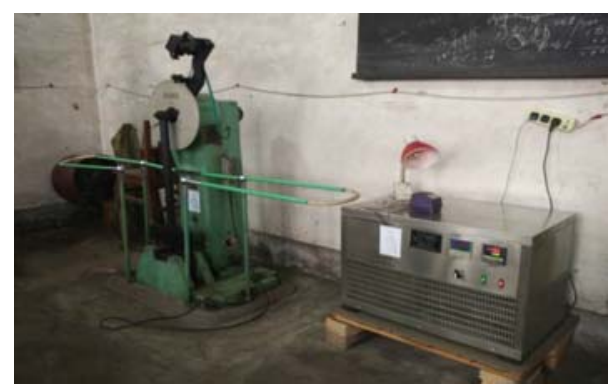

(b) The Pendulum Impact Testing Machine

Figure 4. Material Properties Testing Machines 


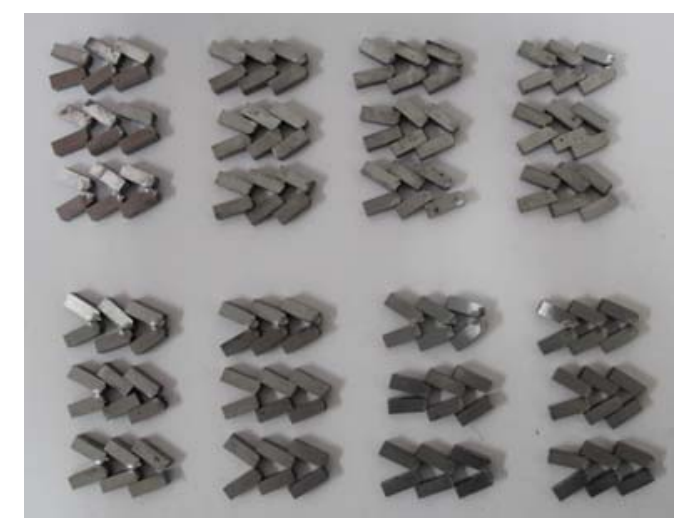

(a) Specimens after impact test

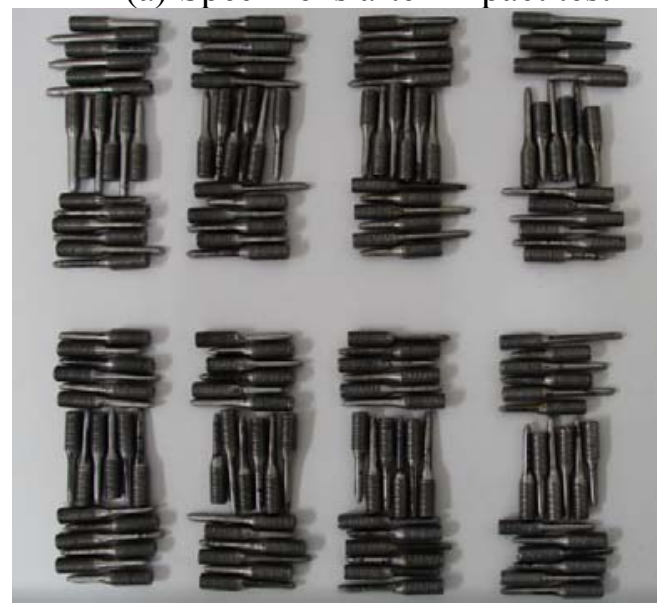

(b) Specimens after Tensile Test

Figure 5. Specimens after Experimental Test

\section{TEST RESULTS AND DISCUSSION}

\subsection{Low Temperature Impact Test}

In structural engineering, the Charpy impact energy $A_{k V}$ is widely employed as material toughness measurement in design as it partially reflects the fracture resistant ability of steel [19].

The Charpy impact tests of Q235B and Q345B were performed at 22 specified temperature points from $100^{\circ} \mathrm{C}$ to $-60^{\circ} \mathrm{C}$ and the corresponding Charpy impact energy $A k V$ are listed in Table 4 . Similarly, the Charpy impact tests of Q420C steel angles and the butt weld joints were performed at each specified temperature points (i.e., $20,0,-20,-60^{\circ} \mathrm{C}$ ) with the Charpy impact energy $A_{k V}$ presented in Table 5.

In this paper, the relationship between the impact energy $A_{k V}$ and temperature is regressed by Boltzmann function in Eq. 1 which is widely used for great dispersion of experimental data. Large quantities of experimental researches have shown that the Boltzmann function can well establish the correlation between impact energy and temperature [19], because it leads to minimal residuals with clear physical meanings of all parameters.

$y=\frac{A_{1}-A_{2}}{1+e^{\left(t-t_{0}\right) / \Delta t}}+A_{2}$ 
Table 4. Charpy Impact Energy $A_{k V}(\mathrm{~J})$ of Q235B and Q345B Steel Angles

\begin{tabular}{|c|c|c|c|c|c|c|c|c|c|c|c|c|}
\hline \multirow{10}{*}{ Q235B } & $\mathrm{T} /{ }^{\circ} \mathrm{C}$ & 100 & 80 & 70 & 60 & 50 & 40 & 30 & 20 & 10 & 0 & -5 \\
\hline & \multirow{4}{*}{$A_{k V} / \mathbf{J}$} & 153 & 119 & 151 & 112 & 121 & 148 & 129 & 171 & 182 & 56 & 36 \\
\hline & & 119 & 129 & 156 & 161 & 120 & 130 & 158 & 168 & 187 & 46 & 25 \\
\hline & & 167 & 145 & 117 & 152 & 152 & 138 & 143 & 184 & 89 & 60 & 26 \\
\hline & & 112 & 116 & 154 & 143 & 112 & 138 & 160 & 174 & 165 & 42 & 29 \\
\hline & \multirow[t]{2}{*}{$\mathrm{T} /{ }^{\circ} \mathrm{C}$} & -10 & -15 & -20 & -25 & -30 & -35 & -40 & -45 & -50 & -55 & -60 \\
\hline & & 23 & 17 & 12 & 8 & 4 & 8 & 5 & 6 & 6 & 3 & 3 \\
\hline & \multirow{3}{*}{$A_{k V} / \mathbf{J}$} & 14 & 14 & 11 & 9 & 9 & 7 & 8 & 4 & 7 & 3 & 4 \\
\hline & & 15 & 17 & 17 & 9 & 5 & 5 & 4 & 5 & 4 & 4 & 4 \\
\hline & & 17 & 16 & 10 & 10 & 7 & 5 & 5 & 5 & 4 & 5 & 3 \\
\hline \multirow{10}{*}{ Q345B } & \multirow[t]{2}{*}{$\mathrm{T} /{ }^{\circ} \mathrm{C}$} & 100 & 80 & 70 & 60 & 50 & 40 & 30 & 20 & 10 & 0 & -5 \\
\hline & & 112 & 122 & 152 & 175 & 155 & 169 & 93 & 153 & 106 & 62 & 85 \\
\hline & \multirow{3}{*}{$A_{k V} / \mathrm{J}$} & 161 & 132 & 151 & 173 & 150 & 175 & 169 & 141 & 131 & 56 & 58 \\
\hline & & 185 & 164 & 174 & 113 & 125 & 163 & 164 & 153 & 103 & 54 & 60 \\
\hline & & 149 & 131 & 159 & 154 & 161 & 169 & 159 & 152 & 114 & 57 & 68 \\
\hline & \multirow[t]{2}{*}{$\mathrm{T} /{ }^{\circ} \mathrm{C}$} & -10 & -15 & -20 & -25 & -30 & -35 & -40 & -45 & -50 & -55 & -60 \\
\hline & & 49 & 40 & 22 & 39 & 15 & 27 & 10 & 8 & 10 & 8 & 7 \\
\hline & \multirow{3}{*}{$A_{k V} / \mathbf{J}$} & 45 & 41 & 24 & 29 & 35 & 10 & 12 & 7 & 7 & 5 & 5 \\
\hline & & 45 & 55 & 35 & 25 & 12 & 16 & 11 & 9 & 6 & 6 & 5 \\
\hline & & 46 & 33 & 22 & 30 & 16 & 7 & 11 & 8 & 8 & 7 & 6 \\
\hline
\end{tabular}

Table 5. Charpy Impact Energy $A_{k V}(\mathrm{~J})$ of Q420C Steel Angles and Welded Joints

\begin{tabular}{ccccccccc}
\hline Steel grade/Type & \multicolumn{4}{c}{ Q420C/Steel angle } & \multicolumn{5}{c}{ Q420C/Welded joint } \\
\hline $\mathrm{T} /{ }^{\circ} \mathrm{C}$ & 20 & -20 & -45 & -60 & 20 & -20 & -45 & -60 \\
\hline & 92 & 105 & 40 & 22 & 158 & 46 & 33 & 7 \\
& 91 & 103 & 31 & 20 & 122 & 63 & 30 & 12 \\
& 143 & 101 & 36 & 15 & 163 & 52 & 25 & 13 \\
$A_{k V} / \mathrm{J}$ & 171 & 122 & 76 & 38 & 172 & 63 & 39 & 16 \\
& 177 & 140 & 57 & 60 & 152 & 39 & 26 & 19 \\
& 176 & 149 & 69 & 58 & 131 & 71 & 21 & 25 \\
& 153 & 131 & 83 & 22 & 126 & 58 & 35 & 29 \\
& 176 & 124 & 82 & 18 & 111 & 73 & 36 & 28 \\
& 176 & 115 & 39 & 61 & 154 & 57 & 48 & 27 \\
\hline
\end{tabular}

In Eq. $1, \mathrm{y}$ is the value of impact energy; $t$ represents the temperature variable; $A_{1}$ and $A_{2}$ are the Charpy impact energy values of the lower and upper shelf respectively; $t_{0}$ is the transition temperature of ductile to brittle; $\Delta t$ is the temperature transition interval, which reflects the ductile-brittle transition rate. The parameters $A_{1}, A_{2}, t_{0}$ and $\Delta t$ are determined by curve-fitting technique with test data. The smaller of $\Delta t$, the narrower of the temperature range across the transition temperature region, and the material is easier from ductile to brittle.

The Charpy impact test results of Q235B, Q345B and Q420C steel angles as well as Q420C welded joints at low temperature and the curves obtained by fitting Boltzmann function are plotted in Figure 6. 
Table 6. Parameters in Boltzmann Function by Curve-fitting

\begin{tabular}{cccccc}
\hline $\begin{array}{c}\text { Steel } \\
\text { grade }\end{array}$ & Type & $\begin{array}{c}\text { The lower shelf } \\
A_{1} / \mathrm{J}\end{array}$ & $\begin{array}{c}\text { The upper shelf } \\
\mathrm{A}_{2} / \mathrm{J}\end{array}$ & $\begin{array}{c}\text { Brittle-ductile } \\
\text { transition temperature } \\
t_{0} /{ }^{\circ} \mathrm{C}\end{array}$ & $\begin{array}{c}\text { temperature } \\
\text { transition interval } \\
\Delta t /{ }^{\circ} \mathrm{C}\end{array}$ \\
\hline $\mathrm{Q} 235 \mathrm{~B}$ & $\begin{array}{c}\text { Steel } \\
\text { angle }\end{array}$ & 8.93 & 143.93 & 1.46 & 2.33 \\
$\mathrm{Q} 345 \mathrm{~B}$ & $\begin{array}{c}\text { Steel } \\
\text { angle }\end{array}$ & 10.02 & 154.75 & 1.03 & 10.01 \\
$\mathrm{Q} 420 \mathrm{C}$ & $\begin{array}{c}\text { Steel } \\
\text { angle }\end{array}$ & 27.27 & 153.44 & -31.74 & 10.99 \\
$\mathrm{Q} 420 \mathrm{C}$ & $\begin{array}{c}\text { Welded } \\
\text { joint }\end{array}$ & 19.56 & 143.22 & -12.69 & 10.22 \\
\hline
\end{tabular}

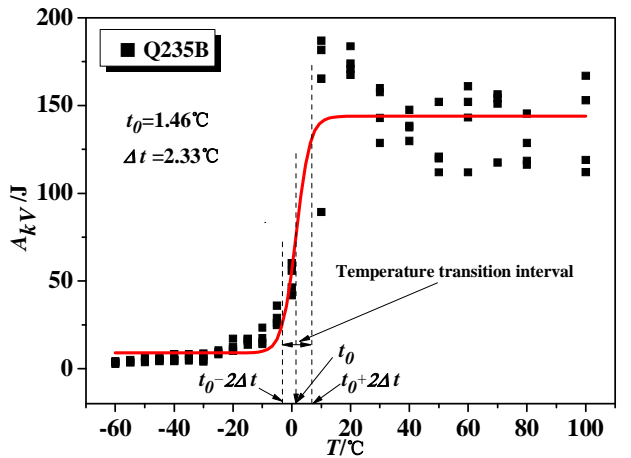

(a) Q235B Steel Angle

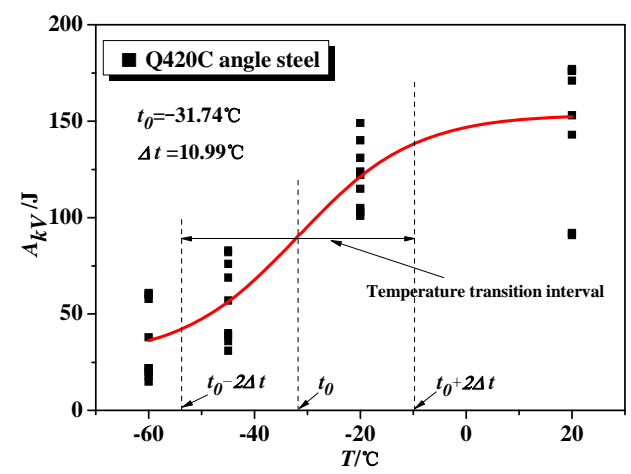

(c) Q420C Steel Angle

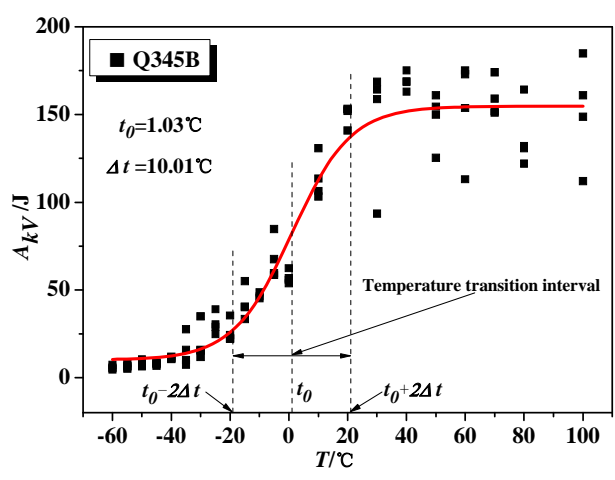

(b) Q345B Steel Angle

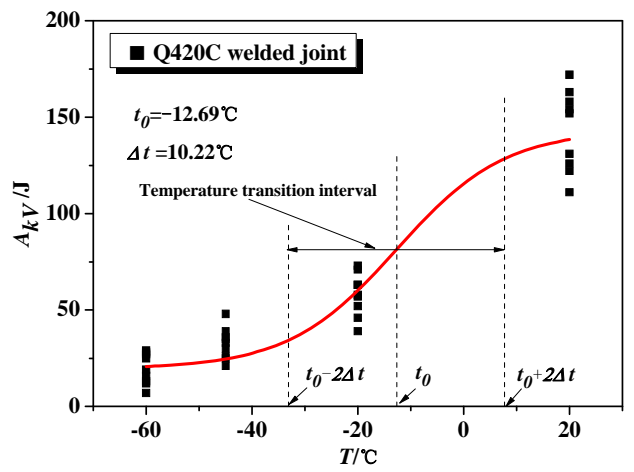

(d) Q420C Welded Joint

Figure 6. Low Temperature Impact Test Results

As shown in Figure 6, the impact energy of four kinds of materials decreases with the decrease of temperature starting at $20^{\circ} \mathrm{C}$. The impact energy reduces rapidly with the decrease of temperature until reaching a certain temperature. The fitting results such as $A_{1}, A_{2}$, to and $\Delta t$ in Boltzmann function are listed in Table 6.

It is clearly shown in Figures $6 \mathrm{a}$ and $6 \mathrm{~b}$ that the curve of the temperature transition interval of Q235B is more rapid than $\mathrm{Q} 345 \mathrm{~B}$, which indicates that $\mathrm{Q} 235 \mathrm{~B}$ more likely becomes brittle at low temperature. From Table 6, it is also found that $t_{0}$ of Q345B steel angle is $0.44^{\circ} \mathrm{C}$ which is lower than $\mathrm{Q} 235 \mathrm{~B}$; $\Delta t$ of $\mathrm{Q} 345 \mathrm{~B}$ steel angle is $7.67^{\circ} \mathrm{C}$ which is higher than $\mathrm{Q} 235 \mathrm{~B}$. Therefore, the ability to resist low temperature and cold brittleness of Q345B is higher than Q235B. 
As shown in Table 6, the ductile-brittle transition temperature of Q235B, Q345B and Q420C steel angles are $1.46^{\circ} \mathrm{C}, 1.03^{\circ} \mathrm{C}$ and $-31.74^{\circ} \mathrm{C}$ respectively. The ductile-brittle transition temperature of $\mathrm{Q} 420 \mathrm{C}$ steel angles is about $-33^{\circ} \mathrm{C}$ lower than Q235B and Q345B steel angle. Thus, the ability of Q420C steel angles to resist low temperature and cold brittleness is better than Q235B and Q345B steel angles.

The ductile-brittle transition temperature of Q420C steel angles and welded joints are $-31.74^{\circ} \mathrm{C}$ and $12.69^{\circ} \mathrm{C}$ respectively. Clearly, the ability of Q420C welded joints to resist low temperature and cold brittleness is much lower than its parent material.

From the above, Q420C steel angles are recommended in the region at low temperature, but the use of Q420C welded joints should be minimized.

\subsection{Low Temperature Tensile Tests}

In the design of lattice transmission tower, the mechanical properties of angle steel such as yield strength $\sigma_{s}$ and ultimate tensile strength $\sigma_{b}$ as well as the ultimate-to-yield strength ratio are vital for the determination of load resistance of steel member.

The mechanical properties of Q235B and Q345B steel angles at 7 specified temperature points from $20^{\circ} \mathrm{C}$ to $-50^{\circ} \mathrm{C}$ are presented. The values of yield strength $\sigma_{s}$ and ultimate tensile strength $\sigma_{b}$ as well as the ultimate-to-yield strength ratio for five tested specimens under seven temperature points are listed in Table 7. Similarly, the mechanical properties of steel angles and butt welded joints made of Q420C were performed at several specified temperature points (i.e. $20,0,-20,-45^{\circ} \mathrm{C}$ ). The values of yield strength $\sigma_{s}$ and ultimate tensile strength $\sigma_{b}$ as well as the ultimate-to-yield strength ratios for the nine tested specimens under four temperature points are listed in Table 8.

Extensive theoretical and experimental researches indicated that, in the temperature range from $-70^{\circ} \mathrm{C}$ to $20^{\circ} \mathrm{C}$, the variations of yield strength and ultimate tensile strength with temperature can be expressed by Eqs. 2 to 4 as follows [20],

$$
\begin{aligned}
& \sigma_{s}=\sigma_{s}^{\prime} e^{q_{s}\left(T^{\prime}-T\right)} \\
& \sigma_{b}=\sigma_{b}^{\prime} e^{\left.q_{b} T^{\prime}-T\right)} \\
& k=q_{b} / q_{s}
\end{aligned}
$$

where $\sigma_{s}, \sigma_{s}^{\prime}$ and $\sigma_{b}, \sigma_{b}^{\prime}$ are the yield strength and ultimate tensile strength at temperature $T$ and $T^{\prime}$ respectively; $q_{s}$ and $q_{b}$ are the temperature sensitive factors of yield strength and ultimate tensile strength respectively; $k$ is the ratio of $q_{b}$ and $q_{s}$.

In addition, the yield-to-ultimate strength ratio of angle steel with considering temperature can be derived from the Eqs. 2 and 3.

$\frac{\sigma_{s}}{\sigma_{b}}=\frac{\sigma_{s}^{\prime}}{\sigma_{b}^{\prime}} e^{\left(q_{s}-q_{b}\right)\left(T^{\prime}-T\right)}$ 
Table 7. Mechanical Properties of Q235B and Q345B Steel Angles from Tensile Test

\begin{tabular}{|c|c|c|c|c|c|c|c|c|}
\hline \multirow{2}{*}{ Steel grade } & \multirow{2}{*}{ Property } & \multicolumn{7}{|c|}{$\mathrm{T} /{ }^{\circ} \mathrm{C}$} \\
\hline & & 20 & 0 & -10 & -20 & -30 & -40 & -50 \\
\hline \multirow{13}{*}{ Q235B } & \multirow{5}{*}{$\sigma_{b} / \mathrm{MPa}$} & 418 & 406 & 452 & 460 & 473 & 488 & 491 \\
\hline & & 422 & 442 & 465 & 501 & 485 & 477 & 508 \\
\hline & & 402 & 443 & 474 & 516 & 461 & 500 & 512 \\
\hline & & 396 & 436 & 500 & 456 & 476 & 482 & 501 \\
\hline & & 368 & 450 & 501 & 461 & 467 & 486 & 483 \\
\hline & Mean & 401.20 & 435.40 & 478.40 & 478.80 & 472.40 & 486.60 & 499.00 \\
\hline & \multirow{5}{*}{$\sigma_{s} / \mathrm{MPa}$} & 243 & 242 & 302 & 315 & 315 & 330 & 358 \\
\hline & & 298 & 288 & 279 & 396 & 337 & 337 & 369 \\
\hline & & 236 & 277 & 348 & 402 & 314 & 353 & 375 \\
\hline & & 224 & 311 & 394 & 295 & 292 & 358 & 374 \\
\hline & & 206 & 298 & 405 & 281 & 292 & 329 & 324 \\
\hline & Mean & 241.40 & 283.20 & 345.60 & 337.80 & 310.00 & 341.40 & 360.00 \\
\hline & $\sigma_{b} / \sigma_{s}$ & 1.66 & 1.54 & 1.38 & 1.42 & 1.52 & 1.43 & 1.39 \\
\hline \multirow{13}{*}{ Q345B } & \multirow{5}{*}{$\sigma_{b} / \mathrm{MPa}$} & 548 & 560 & 570 & 575 & 600 & 601 & 612 \\
\hline & & 549 & 569 & 576 & 588 & 573 & 609 & 612 \\
\hline & & 550 & 562 & 568 & 578 & 591 & 618 & 606 \\
\hline & & 543 & 560 & 578 & 577 & 589 & 605 & 608 \\
\hline & & 539 & 557 & 568 & 580 & 588 & 624 & 610 \\
\hline & Mean & 545.80 & 561.60 & 572.00 & 579.60 & 588.20 & 611.40 & 609.60 \\
\hline & \multirow{5}{*}{$\sigma_{s} / \mathrm{MPa}$} & 348 & 344 & 386 & 371 & 437 & 408 & 397 \\
\hline & & 426 & 416 & 423 & 443 & 386 & 458 & 403 \\
\hline & & 407 & 348 & 378 & 379 & 391 & 437 & 390 \\
\hline & & 346 & 346 & 423 & 376 & 390 & 434 & 409 \\
\hline & & 361 & 377 & 362 & 382 & 385 & 468 & 407 \\
\hline & Mean & 377.60 & 366.20 & 394.40 & 390.20 & 397.80 & 441.00 & 401.20 \\
\hline & $\sigma_{b} / \sigma_{s}$ & 1.45 & 1.53 & 1.45 & 1.49 & 1.48 & 1.39 & 1.52 \\
\hline
\end{tabular}

The temperature sensitivity coefficients $q_{s}$ and $q_{b}$ and the ratio $k$ in Eqs. 2 to 4 for Q235B, Q345B and Q420C steel angles as well as Q420C welded joints at six temperature points from $0^{\circ} \mathrm{C}$ to $-50^{\circ} \mathrm{C}$ are determined from tests and listed in Table 9.

The mechanical properties such as yield strength $\sigma_{s}$ and ultimate tensile strength $\sigma_{b}$ of Q235B and $\mathrm{Q} 345 \mathrm{~B}$ steel angles at seven temperature points from $-20^{\circ} \mathrm{C}$ to $-50^{\circ} \mathrm{C}$, and the average value curve of test results and their prediction curves from these equations are shown in Figure 7 and Figure 8 . The mechanical property indices of Q420C angle steel and its welded joint test results at four temperature points(i.e. $20,0,-20,-45^{\circ} \mathrm{C}$ )and their prediction curves of test results are shown in Figure 9.

As shown in Table 9, the temperature sensitivity coefficients $q_{s}$ and $q_{b}$ of Q235B and Q345B are all positive. According to Eqs. 2 and 3, the positive temperature sensitivity coefficients indicates that the yield strength $\sigma_{s}$ and ultimate tensile strength $\sigma_{b}$ of Q235B and Q345B angle steel are increased with decreasing of temperature. It also can be seen in Table 9 that, the parameter $k$ of $\mathrm{Q} 235 \mathrm{~B}$ is less than 1 while the parameter $k$ of Q345B is greater than 1. It means that for Q235B angle steel at low temperature the increment of $\sigma_{b}$ is smaller than $\sigma_{s}$, while the increment of $\sigma_{b}$ is larger than $\sigma_{s}$ for Q345B angle steel. 
Table 8. Mechanical Properties of Q420C Steel Angles and Butt Welded Joints

\begin{tabular}{ccccccccc}
\hline Property & \multicolumn{3}{c}{ Q 420C/Steel angle } \\
\hline $\mathrm{T} /{ }^{\circ} \mathrm{C}$ & 20 & -10 & -20 & -45 & 20 & -10 & -20 & -45 \\
\hline & 654 & 671 & 690 & 699 & 557 & 541 & 587 & 584 \\
& 660 & 680 & 683 & 698 & 557 & 574 & 581 & 585 \\
& 657 & 677 & 693 & 702 & 553 & 528 & 573 & 550 \\
$\sigma_{b} /$ & 572 & 612 & 610 & 606 & 514 & 514 & 539 & 561 \\
$\mathrm{MPa}$ & 571 & 594 & 604 & 598 & 510 & 526 & 530 & 546 \\
& 572 & 591 & 607 & 603 & 510 & 546 & 537 & 511 \\
& 620 & 640 & 641 & 663 & 600 & 575 & 636 & 643 \\
& 622 & 646 & 648 & 664 & 601 & 611 & 611 & 630 \\
$\mathrm{Mean}$ & 615.67 & 638.89 & 646.89 & 655.33 & 554.11 & 553.22 & 578.33 & 584.00 \\
\hline & 460 & 479 & 543 & 517 & 450 & 457 & 486 & 446 \\
& 474 & 496 & 519 & 522 & 444 & 443 & 471 & 460 \\
& 485 & 491 & 521 & 531 & 429 & 423 & 450 & 486 \\
& 413 & 441 & 496 & 445 & 412 & 433 & 452 & 468 \\
\hline$\sigma_{b} / \sigma_{s}$ & 1.34 & 1.35 & 1.29 & 1.34 & 1.28 & 1.27 & 1.25 & 1.24 \\
\hline $\mathrm{MPa}$ & 427 & 442 & 479 & 425 & 415 & 449 & 455 & 470 \\
& 448 & 447 & 469 & 432 & 398 & 397 & 440 & 451 \\
& 487 & 487 & 486 & 521 & 449 & 437 & 472 & 500 \\
& 477 & 492 & 503 & 505 & 455 & 446 & 464 & 484 \\
& 467 & 475 & 499 & 510 & 454 & 432 & 474 & 475 \\
\hline
\end{tabular}

Table 9. Temperature Sensitivity Coefficients

\begin{tabular}{|c|c|c|c|c|c|c|}
\hline $\begin{array}{c}\text { Steel } \\
\text { grade/Type }\end{array}$ & $T^{\circ} \mathrm{C}$ & $q_{s} /(10$ & $-1)$ & $q_{b} /(10$ & $\left.\mathrm{C}^{-1}\right)$ & $k$ \\
\hline \multirow{6}{*}{$\begin{array}{c}\text { Q235B/ } \\
\text { Steel angle }\end{array}$} & 0 & 7.98 & \multirow{6}{*}{7.47} & 4.09 & \multirow{6}{*}{4.00} & \multirow{6}{*}{0.53} \\
\hline & -10 & 11.96 & & 5.87 & & \\
\hline & -20 & 8.40 & & 4.42 & & \\
\hline & -30 & 5.00 & & 3.27 & & \\
\hline & -40 & 5.78 & & 3.22 & & \\
\hline & -50 & 5.71 & & 3.12 & & \\
\hline \multirow{6}{*}{$\begin{array}{c}\text { Q345B/ } \\
\text { Steel angle }\end{array}$} & 0 & -1.53 & \multirow{6}{*}{0.87} & 1.43 & \multirow{6}{*}{1.58} & \multirow{6}{*}{1.81} \\
\hline & -10 & 1.45 & & 1.56 & & \\
\hline & -20 & 0.82 & & 1.50 & & \\
\hline & -30 & 1.04 & & 1.50 & & \\
\hline & -40 & 2.59 & & 1.89 & & \\
\hline & -50 & 0.87 & & 1.58 & & \\
\hline \multirow{3}{*}{$\begin{array}{c}\text { Q420C/ } \\
\text { Steel angle }\end{array}$} & -10 & 0.89 & \multirow{3}{*}{1.35} & 1.23 & \multirow{3}{*}{1.14} & \multirow{3}{*}{0.85} \\
\hline & -20 & 2.18 & & 1.24 & & \\
\hline & -45 & 0.97 & & 0.96 & & \\
\hline \multirow{3}{*}{$\begin{array}{c}\text { Q420C/ } \\
\text { Welded joint }\end{array}$} & -10 & 0.09 & \multirow{3}{*}{0.99} & -0.05 & \multirow{3}{*}{0.61} & \multirow{3}{*}{0.62} \\
\hline & -20 & 1.60 & & 1.07 & & \\
\hline & -45 & 1.26 & & 0.81 & & \\
\hline
\end{tabular}


As shown in Table 9, the temperature sensitivity coefficients $q_{s}$ and $q_{b}$ of Q420C steel angles and its welded joint are also all positive, which indicate that the yield strength $\sigma_{s}$ and ultimate tensile strength $\sigma_{b}$ of Q420C angle steel and its welded joint are also increased with decreasing of temperature. The parameter $k$ of Q420C steel angles and its welded joint at low temperature are all less than 1, which indicate that the increment of $\sigma_{b}$ is smaller than $\sigma_{s}$.

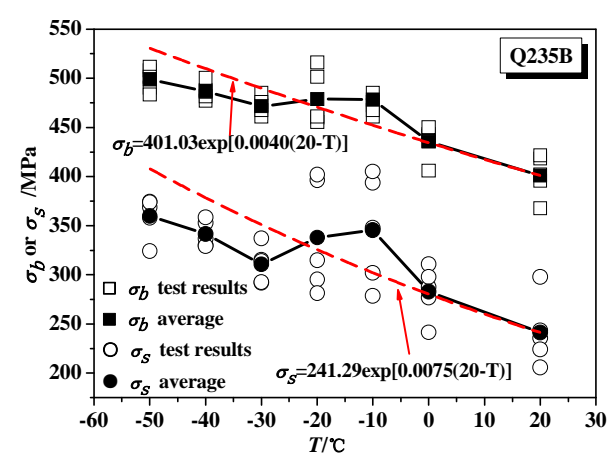

(a) Ultimate and Yield Tensile Strength

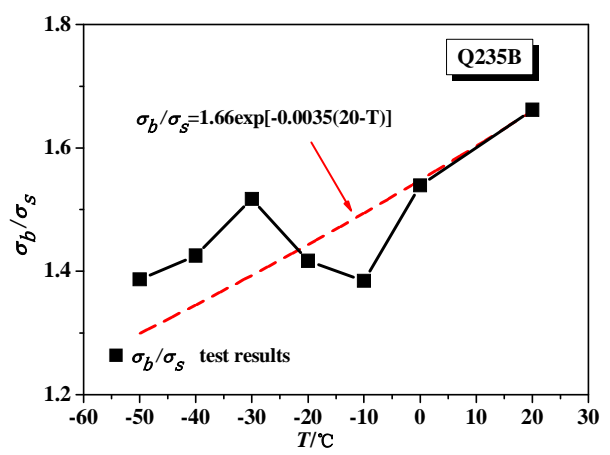

(b) Ultimate-to-yield Strength Ratio Figure 7. Mechanical Property Indices of Q235B Steel Angles

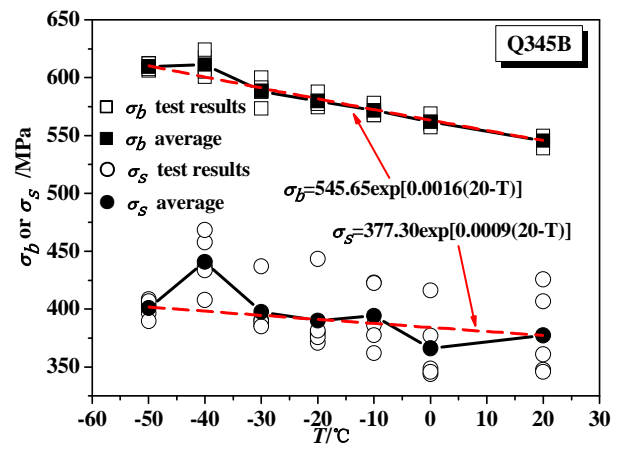

(a) Ultimate and Yield Tensile Strength

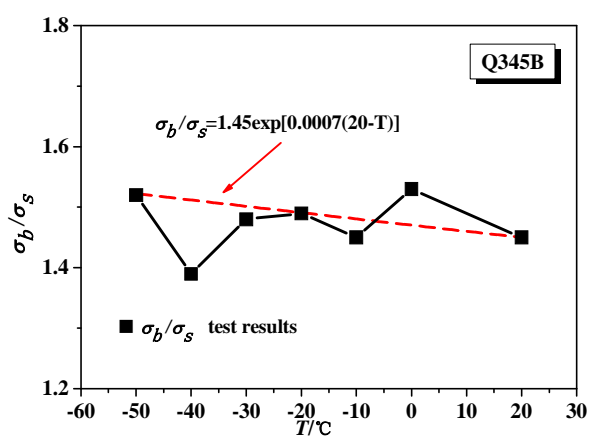

(b) Ultimate-to-yield Strength Ratio

Figure 8. Mechanical Property Indices of Q345B Steel Angles
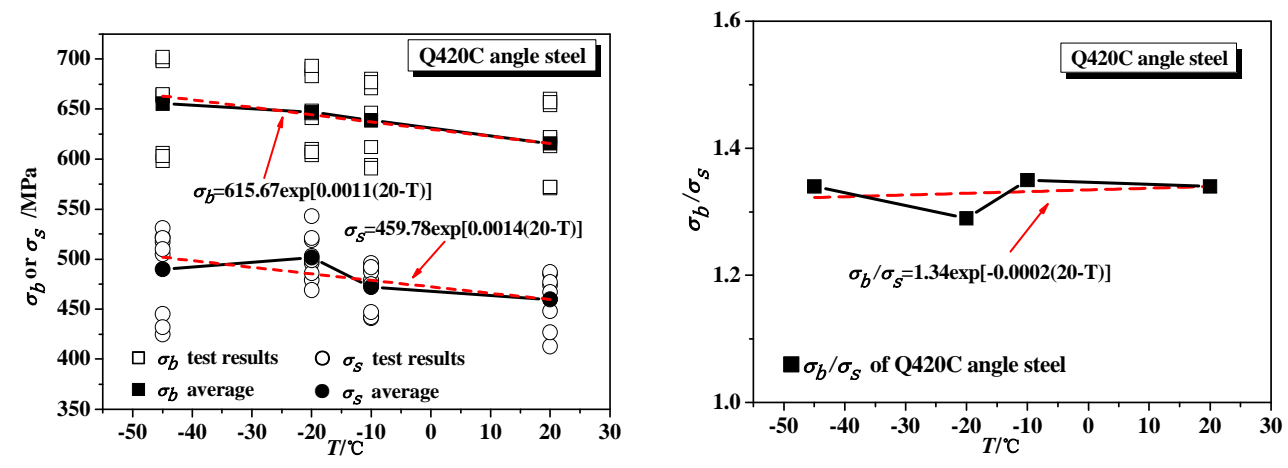

(a) Ultimate and Yield Tensile Strength

(b) Ultimate-to-yield Strength Ratio

Figure 9. Mechanical Property Indices of Q420C Steel Angles 


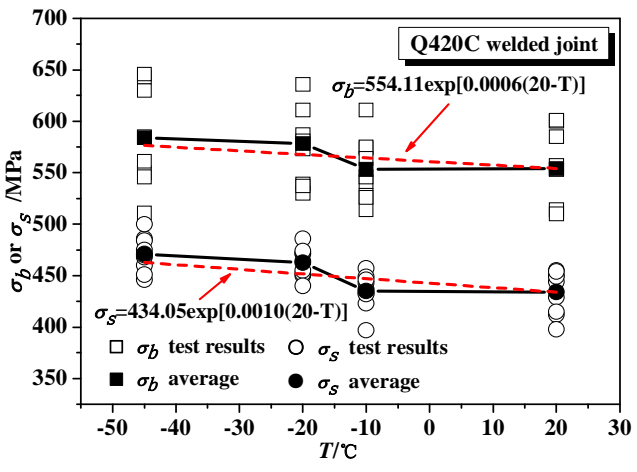

(a) Ultimate and Yield Tensile Strength

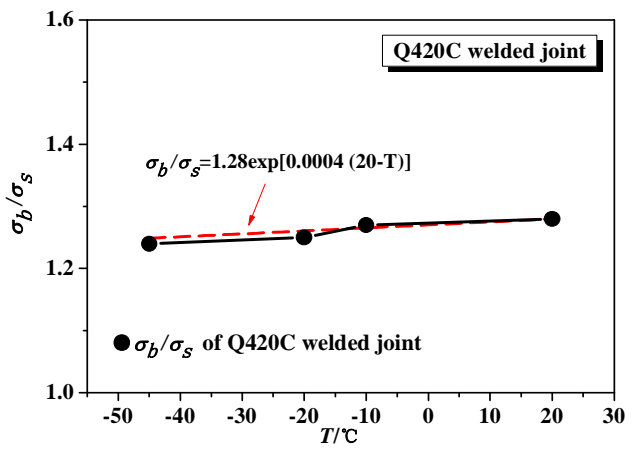

(b) Ultimate-to-yield Strength Ratio

Figure 10. Mechanical Property Indices of Q420C Weld Joints

Figure 7 shows the mechanical property indices of Q235B steel angles from $-50^{\circ} \mathrm{C}$ to $20^{\circ} \mathrm{Cincluding}$ yield strength, ultimate tensile strength and ultimate-to-yield strength ratio as well as its prediction curves based on Eqs. 2 to 3. The yield strength $\sigma_{s}$ and ultimate tensile strength $\sigma_{b}$ of Q235B steel angle are increased from 241.40 $\mathrm{MPa}$ and $401.20 \mathrm{MPa}$ to $360.00 \mathrm{MPa}$ and $499.00 \mathrm{MPa}$ respectively (see Figure 7a). It is clear that the yield strength and ultimate tensile strength are increased with increasing temperature. As shown in Figure 7b, the ultimate-to-yield ratios $\sigma_{b} / \sigma_{s}$ of Q235B steel angel is dramatically decreased from 1.66 to 1.39 as the temperature decreased from $20^{\circ} \mathrm{C}$ to $-50^{\circ} \mathrm{C}$, which indicates the brittleness increased and plasticity decreased at low temperature.

Figure 8 shows the mechanical property indices as well as its prediction curves of Q345B steel angles from $-50^{\circ} \mathrm{C}$ to $20^{\circ} \mathrm{C}$. It can be seen in Figure $8 \mathrm{a}$ that, the yield strength and ultimate tensile strength are increased from $377.60 \mathrm{MPa}$ and $545.80 \mathrm{MPa}$ to $401.20 \mathrm{MPa}$ and $609.60 \mathrm{MPa}$ respectively. However, as shown in Figure 8b, the ultimate-to-yield ratios are changed and different from Q235B (see Figure $7 \mathrm{~b}$ ), which are varied between 1.45 and 1.53, and slightly increased with decreasing of temperature.

Figure 9 shows the mechanical property indices as well as its prediction curves of Q420C steel angles from $-45^{\circ} \mathrm{C}$ to $20^{\circ} \mathrm{C}$. As shown in Figure $9 \mathrm{a}$, when the temperature decreases from $20^{\circ} \mathrm{C}$ to $-45^{\circ} \mathrm{C}$, the yield strength and ultimate tensile strength of Q420C steel angle are increased from $459.78 \mathrm{MPa}$ and 615.67 $\mathrm{MPa}$ to $489.78 \mathrm{MPa}$ and $655.33 \mathrm{MPa}$ respectively. It can be seen in Figure 9b, the ultimateto-yield ratios of Q420C steel angles are varied between 1.29 and 1.35, which is also different from Q235B.

Figure 10 shows the mechanical property indices as well as its prediction curves of Q420B weld joints from $-45^{\circ} \mathrm{C}$ to $20^{\circ} \mathrm{C}$. As shown in Figure $10 \mathrm{a}$, with the temperature decreases from $20^{\circ} \mathrm{C}$ to $45^{\circ} \mathrm{C}$, the yield strength and the ultimate tensile strength of Q420C welded joints are increased from 434.05 MPa and 554.10 MPa to 471.11 MPa and 655.33 MPa respectively. It can be seen in Figure 10b, the ultimate-to-yield ratios of Q420C welded joints are varied between 1.24 and 1.27.

As shown in Figures 7a, 8a and 9a, the yield strength and tensile strength of Q235B, Q345B and Q420C steel angles are all increased with the decrease of temperature. However, the temperature has more influence on the yield strength and tensile strength of Q235B steel angels than the Q345B and Q420C steel angels as the slop of the Q235B curves is greater than the others. It can be concluded that the influence of low temperature on yield strength and tensile strength will decrease with the increase of steel grade. 
As shown in Figures 9a and 10a, the influence of low temperature on the yield strength and tensile strength of Q420C steel angles and its weld joints is quite similar. Taking yield strength for example, the yield strength of Q420C steel angels and its weld joints is slightly increased from $459.78 \mathrm{MPa}$ and $434.05 \mathrm{MPa}$ to $489.78 \mathrm{MPa}$ and $471.11 \mathrm{MPa}$ respectively with the temperature decreasing from $20^{\circ} \mathrm{C}$ to $-45^{\circ} \mathrm{C}$.

Figures $7 \mathrm{~b}, 8 \mathrm{~b}, 9 \mathrm{~b}$ and $10 \mathrm{~b}$ show the ultimate-to-yield ratio versus temperature curves of Q235B, Q345B and Q420C steel angles and Q420C weld joints. It can be seen from the figures, the influence of temperature on the ultimate-to-yield ratio is quite different. The ultimate-to-yield ratio of Q235B steel angle is dramatically decreased from 1.66 to 1.39 , while Q345B and Q420C steel angles are varied between 1.45 and 1.53, 1.29 and 1.35 respectively. Hence, it is clear that the low temperature will dramatically increase the yield strength, tensile strength and brittleness of Q235B steel angles and decrease plasticity; but the low temperature has less influence on Q345B and Q420C steel angles and Q420C weld joints.

\subsection{Notch Sensitivity Tests}

The appearance of microcrack around bolt hole will affect the mechanical performance of steel angels at low temperature. In practice, steel members with notch become brittle under three-dimensional stress state and strain concentration occurs which is called the notch sensitivity. To evaluate the notch sensitivity of steel angels at low temperature, the notch sensitivity factor and the stress concentration coefficient of notch specimens are expressed in Eqs. 6 to 7 as follows [21,22],

$q_{t}=\sigma_{b} / \sigma_{b H}$

$K_{t}=\sigma_{b H} / \sigma_{s}$

where $\sigma_{b}$ is the ultimate tensile strength of the smooth specimen, $\sigma_{b H}$ is the ultimate tensile strength of specimen with notch, $\sigma_{s}$ is the yield stress as the appearance of non-proportional elongation of smooth specimens. It can be seen from the equations, the notch sensitivity factor is defined as the ratio of $\sigma_{b}$ and $\sigma_{b H}$, the stress concentration coefficient is the ratio of $\sigma_{b H}$ and $\sigma_{s}$. Thus, the smaller of $q_{t}$ and $K_{t}$, the smaller influence of notch.

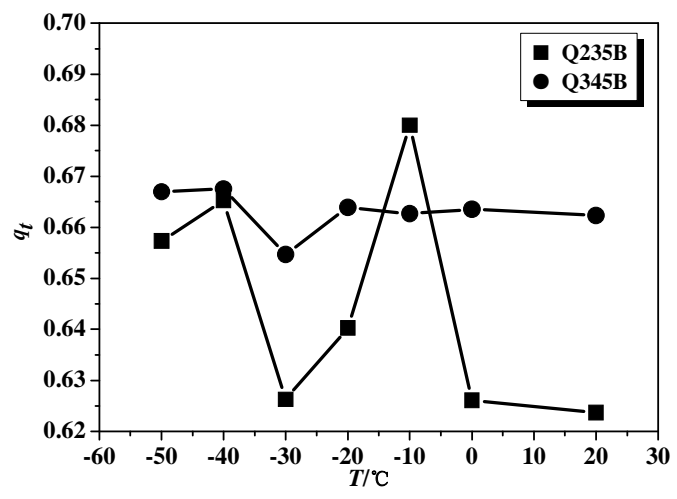

Figure 11. Notch Sensitivity Factors

The tensile tests of Q235B and Q345B steel angles were performed at seven specified temperature points from $20^{\circ} \mathrm{C}$ to $-50^{\circ} \mathrm{C}$. The values of ultimate tensile strength $\sigma_{b}$ for 5 test specimens with 7 specified temperature points are listed in Table 11. According to the yield stress $\sigma_{s}$ and ultimate tensile strength of the smooth specimen $\sigma_{b}$ listed in Table 7, the notch sensitivity factor $q_{t}$ and the 
stress concentration coefficient $K_{t}$ are calculated and listed in Table 10. Figure 11 shows the notch sensitivity factor versus temperature curves.

Table 10. Notch Tensile Test Results of Q235B and Q345B Steel Angles

\begin{tabular}{|c|c|c|c|c|c|c|c|c|}
\hline Steel grade & Property & 20 & 0 & -10 & $\begin{array}{l}\mathrm{T} /{ }^{\circ} \mathrm{C} \\
-20\end{array}$ & -30 & -40 & -50 \\
\hline \multirow{8}{*}{ Q235B } & \multirow{5}{*}{$\begin{array}{l}\text { Ultimate } \\
\text { tensile } \\
\text { strength }\end{array}$} & 623 & 716 & 660 & 701 & 772 & 742 & 765 \\
\hline & & 636 & 651 & 695 & 720 & 739 & 705 & 748 \\
\hline & & 685 & 732 & 709 & 810 & 780 & 714 & 786 \\
\hline & & 638 & 715 & 728 & 770 & 720 & 781 & 749 \\
\hline & & 632 & 663 & 680 & 738 & 753 & 717 & 747 \\
\hline & $\sigma_{b H} / \mathrm{MPa}$ & 642.8 & 695.4 & 694.4 & 747.8 & 752.8 & 731.8 & 759.0 \\
\hline & $q_{t}$ & 0.62 & 0.63 & 0.68 & 0.64 & 0.63 & 0.66 & 0.66 \\
\hline & $K_{\mathrm{t}}$ & 2.66 & 2.46 & 2.01 & 2.21 & 2.43 & 2.14 & 2.11 \\
\hline \multirow{8}{*}{ Q345B } & \multirow{5}{*}{$\begin{array}{l}\text { Ultimate } \\
\text { tensile } \\
\text { strength }\end{array}$} & 823 & 836 & 863 & 878 & 917 & 947 & 916 \\
\hline & & 880 & 881 & 882 & 872 & 884 & 912 & 915 \\
\hline & & 813 & 846 & 864 & 880 & 906 & 939 & 912 \\
\hline & & 792 & 827 & 855 & 870 & 889 & 892 & 902 \\
\hline & & 812 & 843 & 851 & 867 & 896 & 889 & 925 \\
\hline & $\sigma_{b H} / \mathrm{MPa}$ & 824.0 & 846.6 & 863.0 & 873.4 & 898.4 & 915.8 & 914.0 \\
\hline & $q_{t}$ & 0.66 & 0.66 & 0.66 & 0.66 & 0.65 & 0.67 & 0.67 \\
\hline & $K_{\mathrm{t}}$ & 2.18 & 2.31 & 2.19 & 2.24 & 2.26 & 2.08 & 2.28 \\
\hline
\end{tabular}

As shown in Figure 11, the notch sensitivity factor $q_{t}$ of Q345B, which is changed between 0.65 and 0.67 , is slightly increased with the decrease of temperature. Therefore, the temperature has little effect on the notch sensitive coefficient of Q345B steel angles. However, it is clear that the gap sensitive coefficient of Q235B steel angles, which is varied between 0.62 and 0.68 , is much more sensitive to the decrease of temperature. Hence, it can be concluded that the sensitivity of the gap will increase with the increasing of steel grade of angel section. In other words, it should be taken more care on the use of high steel grade angle members at low temperature.

As shown in Table 10, the stress concentration coefficient $K_{t}$ for Q235B steel angle varies between 2.01 and 2.66 while the range of $K_{t}$ is from 2.08 to 2.31 for Q345B. It indicates that there is no clear increasing or decreasing tendency on the stress concentration of the two kinds of steel angles at low temperature. Thus, the effect of low temperature on $K_{t}$ is insignificant. In practice, it is recommended that the stress concentration coefficient $K_{t}$ of steel angles is taken as 3 to prevent the occurrence of brittle fault due to the possible existence of the notch at low temperature.

\section{CONCLUSIONS}

The application of higher strength steel such as Q420 can improve the safety and structural performance of transmission engineering with a reduction in fabrication and construction cost. However, the mechanical properties and toughness of the higher grade steel are different from that of commonly used steel such as Q235 and Q345, due to the different rolling process, crystal phases and chemical components especially under low temperature. The lack of support by experimental tests limits the use of Q420 and Q460 in transmission towers at the low temperature area. This paper fills the gap by carrying out a series of tests such as Charpy impact test, uniaxial tensile test and tensile notch test at low temperatures to investigate the mechanical properties and toughness of steel 
angles made of Q235B, Q345B and Q420C as well as welded joints using Q420C. Several useful conclusions are made for design purpose and presented as follows:

1) The impact energy of steel materials decreases with the decreasing of temperature starting from $20^{\circ} \mathrm{C}$. The ductile-brittle transition temperature of Q235B, Q345B and Q420C steel angles and $\mathrm{Q} 420 \mathrm{C}$ welded joints are $1.47^{\circ} \mathrm{C}, 1.03^{\circ} \mathrm{C},-31.74^{\circ} \mathrm{C}$ and $-12.69^{\circ} \mathrm{C}$, respectively. The ability to resist low temperature and cold brittleness of Q420C steel angles are better than Q235B and Q345B steel angles. Q420C steel angles are preferred in the cold region, but the welded joints of Q420C should be avoided.

2) The tensile strength $\sigma_{b}$ and yield strength $\sigma_{s}$ of Q235B, Q345B and Q420C steel angles and Q420C welded joints are increased with the decreasing of temperature. Also, the increment of $\sigma_{b}$ at low temperature is smaller than $\sigma_{s}$ for Q235B and Q420C steel angles and Q420C welded joints; but the increment of $\sigma_{b}$ is greater than $\sigma_{s}$ for Q345B steel angles. Welding process will significantly reduce the performance of Q420C steel angle and therefore, the welded joints of Q420C steel should be avoided at low temperature conditions.

3) In low temperature region, the design load resistance of steel angles can be calculated by the design strength specified in national design code with the reduction factor obtained from experimental test. The strength reduction factor of Q235B, Q345B and Q420C steel angles and Q420C welded joints are recommended as $0.90,0.90,0.75$ and 0.70 respectively.

4) The effect of low temperature on stress concentration due to microcrack is insignificant. The stress concentration coefficient $K_{t}$ of Q235B and Q345B steel angles is recommended as 3 for connection design of transmission tower. The notch sensitivity factor $q_{t}$ of Q345B is larger than Q235B and therefore, it should take more care on the rolling process and fabrication works on the members made of higher steel grade such as Q420.

\section{ACKNOWLEDGMENT}

The authors acknowledge the financial support provided by the Natural Science Foundation of China (51408221), the Natural Science Foundation of Hebei Province of China (E2015502016), the Fundamental Research Funds for the Central Universities of China (2014ZD36). The third author is grateful to the financial supports by Innovation and Technology Fund of the Hong Kong SAR Government for the project "Development of an energy absorbing device for flexible rock-fall barriers (ITS/059/16FP)".

\section{REFERENCES}

[1] AISC-LRFD. Specification for Structural Steel Buildings. AISC, Inc, One East Wacker Driver, Suite 700, Chicago, Illinois 60601-1802, 2010.

[2] Eurocode3. EN 1993-1-1: Design of Steel Structures - General Rules and Rules for Buildings, European Committee for Standardization. 2005.

[3] Jiang, W. Q., Wang, Z. Q. and McClure, G., et al., "Accurate Modeling of Joint Effects in Lattice Transmission Towers", Engineering Structures, 2011, Vol. 33, No. 5, pp. 1817-1827.

[4] Jiang, W. Q., Liu, Y. P. and Chan, S. L., et al., "Direct Analysis of An Ultrahigh-voltage Lattice Transmission Tower Considering Joint Effects", Journal of Structural Engineering, 2017, Vol. 143,No. 5, pp. 4017009.

[5] Wang, Y. Q., Liu, X. Y. and Hu, Z. W., et al., "Experimental Study on Mechanical Properties 
and Fracture Toughness of Structural Thick Plate and Its Butt Weld along Thickness and at Low Temperatures", Fatigue \& Fracture of Engineering Materials \& Structures, 2013, Vol. 36, No. 12, pp. 1258-1273.

[6] Xu, Y., "Research on the Bearing Capacity of High-strength Steel Tubular H-Joints in HighVoltage Transmission Lines”, Applied Mechanics \& Materials, 2014, Vol. 513-517, pp. 41234126.

[7] Wang, Y. Q., Liu X. Y. and Lin Y., et al., "Experimental Study on Fracture Toughness of HighStrength Structural Steel and Its Butt Weld", Advanced Steel Construction, 2015, Vol. 11, No. 4, pp. 440-451.

[8] Jing, H., Huo L. and Zhang Y., et al., "Effect of Yield Ratio on Fracture Toughness for High Strength Steel", Acta Metallrugica Sinica, 1996, Vol. 32, No. 3, pp. 265-268.

[9] Barsom, J. M. and Rolfe, S.T., "Fracture and Fatigue Control in Structures : Applications of Fracture Mechanics", 1987, No. 5, pp. 83.

[10] Toribio, J., "A Fracture Criterion for High-strength Steel Notched Bars", Engineering Fracture Mechanics, 1997, Vol. 57, No. 4, pp. 391-404.

[11] Rogers, C. A. And Hancock, G. J., "Fracture Toughness of G550 Sheet Steels Subjected to Tension", Journal of Constructional Steel Research, 2001, Vol. 57, No. 1, pp. 71-89.

[12] Yang, F. Y., Li, X. B. and Chen, X., et al., "Study on Low Temperature Service Capabilities and Application of Power Transmission Tower Steel", Proceedings of the CSEE, 2013, Vol. 33, No. 1, pp. 117-122. (in Chinese)

[13] Yu, Z.X., QIAO, Y.K. and ZHAO, L., et.al. “A Simple Analytical Method for Evaluation of Flexible Rockfall Barrier Part 1: Working Mechanism and Analytical Solution”, Advanced Steel Construction.2018, Vol. 14, No. 2, pp.115-141.

[14] Yu, Z.X., QIAO, Y.K. and ZHAO, L., et.al. "A Simple Analytical Method for Evaluation of Flexible Rockfall Barrier Part 2: Application and Full-scale Test”, Advanced Steel Construction. 2018, Vol. 14, No. 2, pp.142-165.

[15] Wang, F.Y., Xu, Y.L. and Zhan, S. "Concurrent Multi-scale Modeling of a Transmission Tower Structure and Its Experimental Verification”, Advanced Steel Construction. 2017, Vol.3 No.3 pp.258-272.

[16] “GB/T2009-2007 Metallic Materials-Charpy Pendulum Impact Test Method", Beijing: China Standards Press, 2008. (in Chinese)

[17] “GB/T 13239-2006 Metallic Materials-Tensile Testing at Low Temperature", Beijing: China Standards Press, 2006. (in Chinese)

[18] HB 5214-1996 Normal Temperature Metal Notch Tensile Test Method", Beijing: China Standards Press, 1996. (in Chinese)

[19] Wang, Y. Q., Liu, X. Y. and Hu, Z. W., et al., "Experimental Study on Mechanical Properties and Toughness of q460c High-strength Steel and its Butt Welded Joint at Low Temperature", Fatigue \& Fracture of Engineering Materials \& Structures, 2014, Vol. 3, No. 14, pp. 456-469.

[20] Wang, Y. Q., Zhou, H. and Shi, Y. J., et al., "Mechanical Properties and Fracture Toughness of Rail Steels and Thermite Welds at Low Temperature", International Journal of Minerals, Metallurgy and Materials, 2012, Vol. 19, No. 5, pp. 409-420.

[21] Može, P., Beg, D. and Lopatič, J., "Net Cross-section Design Resistance and Local Ductility of Elements made of High Strength Steel”, Journal of Constructional Steel Research, 2007, Vol. 63, No. 11, pp. 1431-1441.

[22] Cai, Y. and Young, B., "Structural Behavior of Cold-formed Stainless Steel Bolted Connections", Thin-Walled Structures, 2012, Vol. 83, pp. 147-156. 